\title{
Computational prediction of MicroRNAs targeting GABA receptors and experimental verification of miR-181, miR-216 and miR-203 targets in GABA-A receptor
}

\author{
Chunling Zhao ${ }^{1,2}$, Chaoqun Huang ${ }^{1}$, Tingting Weng ${ }^{1}$, Xiao Xiao ${ }^{1}$, Hong Ma ${ }^{1}$ and Lin Liu ${ }^{1,3^{*}}$
}

\begin{abstract}
Background: GABA receptors are well known as the inhibitory receptors in the central nervous system and are also found in peripheral tissues. We have previously shown that GABA receptors are involved in lung development and fluid homeostasis. However, the microRNAs that regulate GABA receptors have not yet been identified.

Results: In this study, we used the online software, TargetScan and miRanda, to query the microRNAs that directly target GABA receptors and then selected some of them to verify experimentally using 3'-UTR reporter assays. Computational approaches predict many microRNA binding sites on the 3'-UTR of GABA $A_{A}$ receptors, but not on $\mathrm{GABA}_{C}$ receptors. 3'-UTR reporter assays only verified miR-181, miR-216, and miR-203 as the microRNAs that target GABA receptor $\alpha 1$-subunit among 10 microRNAs tested.

Conclusions: Our studies reinforce that microRNA target prediction needs to be verified experimentally. The identification of microRNAs that target GABA receptors provides a basis for further studies of post-transcriptional regulation of GABA receptors.
\end{abstract}

\section{Background}

GABA receptors are well known as the inhibitory receptors in the central nervous system $[1,2]$. However, GABA receptors are also found in several peripheral tissues [3-6]. The functions of GABA receptors in peripheral tissues are less studied. They may be involved in ion homeostasis [7], cell proliferation and differentiation [8], development [1], and hormone secretion [5,9].

We have initially identified GABA receptor $\pi$-subunit as a specific alveolar epithelial type II cell marker through DNA microarray analysis [10]. The expression pattern of the GABA receptor $\pi$-subunit is regulated by various culture conditions and is consistent with the type II cell phenotypes [11]. We have further identified 19 subunits of the ionotropic GABA receptors in alveolar epithelial cells [6]. Their expression is dynamically

\footnotetext{
* Correspondence: lin.liu@okstate.edu

'The Lundberg-Kienlen Lung Biology and Toxicology Laboratory, Department of Physiological Sciences, Oklahoma State University, Stillwater, Oklahoma 74078, USA

Full list of author information is available at the end of the article

changed during lung development [12]. Functionally, GABA receptors play important roles in fluid homeostasis in the adult lung and fetal lung development $[6,13]$.

GABA receptors can be classified into two major types: $\mathrm{GABA}_{\mathrm{A}}$ and $\mathrm{GABA}_{\mathrm{C}}$ as ligand-gated $\mathrm{Cl}^{-}$channels, and $\mathrm{GABA}_{\mathrm{B}}$ receptor as a metabotropic receptor coupled to a heterotrimeric G-protein. $\mathrm{GABA}_{\mathrm{A}}$ and $\mathrm{GABA}_{C}$ receptors share a conserved structure that contains a long extracellular $\mathrm{N}$-terminal region, 4 transmembrane domains (TM1-TM4), a large intracellular loop between TM3 and TM4, and a short extracellular C-terminus $[1,2,14-16]$. The $\mathrm{N}$-terminal segment is responsible for ligand binding and subunit assembly. The TM2 domain forms the lining of the ion pore. The intracellular loop is the site for post-translational modifications and binding with other proteins. This loop harbors a number of consensus phosphorylation sites for protein kinase $\mathrm{A}$ and $\mathrm{C}$ (PKA and PKC) and tyrosine kinases [17].

MicroRNAs are small non-coding RNAs. They form a ribonucleoprotein complex, termed RISC that cleaves 
mRNA or represses protein translation. MicroRNAs regulate various biological processes $[18,19]$. Several microRNAs such as miR-17-92 cluster and miR-127 are involved in lung development [20-22]. MicoRNAs have also been implicated in many lung diseases including lung inflammation, Chronic Obstructive Pulmonary Disease, Asthma and Idiopathic Pulmonary Fibrosis [23-30]. Nevertheless, microRNAs that regulate GABA receptors have not yet been reported. In this study, we used online software, TargetScan (http://www.targetscan.org) [31] and mRanda (http://www.microrna.org) [32] to predict the microRNAs that possibly target to GABA receptors and then selected some of them to verify experimentally using 3'-UTR reporter assays. We found that miR-181, miR-23 and miR-216 target the GABA receptor $\alpha 1$-subunit.

\section{Methods}

Construction of microRNA expression vectors

Human microRNA expression vectors were constructed as previously described [22]. Mature microRNAs with the flanking sequences ( 200 base pairs at each end) were PCR-amplified from human genomic DNA. The primers used for PCR amplification are listed in Table 1. The PCR products were inserted into a modified pLVXPuro lenti-viral vector (Clontech) between CMV-driven enhanced green fluorescent protein (EGFP) and SV40 polyA terminal sequences.

\section{Construction of $3^{\prime}-$ UTR reporter vectors}

The full length 3'-UTR or the microRNA binding sites in the 3'-UTR of rat GABA receptors were PCR-amplified and inserted into the pRL-TK vector containing a Renilla luciferase (Promega). The primers used for PCR amplification are listed in Table 2.

\section{3'-UTR reporter assay}

HEK 293 T cells $\left(2 \times 10^{4} /\right.$ well $)$ were seeded in each well of a 96-well plate. After one day of culture, the cells were transfected with100 ng microRNA expression vector or control vector without miRNA insert, $2.5 \mathrm{ng} 3$ 'UTR Renillia luciferase reporter vector and $15 \mathrm{ng}$ pGL3 control vector (firefly luciferase reporter) using Lipofectamine. After a 2 day transfection, the cells were lyzed and dual luciferase activities were measured using the Dual-Luciferase Reporter Assay System (Promega). The Renilla luciferase activities were normalized with firefly luciferase activity. Data was expressed as a ratio to the control vector without miRNA insert.

\section{Results and discussion}

Both $\mathrm{GABA}_{\mathrm{A}}$ and $\mathrm{GABA}_{\mathrm{C}}$ receptors are ligand-gated $\mathrm{Cl}^{-}$ channels. However $\mathrm{GABA}_{C}$ receptors have very unique ligand binding characteristics in comparison with $\mathrm{GABA}_{\mathrm{A}}$ and $\mathrm{GABA}_{\mathrm{B}}$ receptors, including a high sensitivity to the physiological ligand, GABA, insensitivity to bicuculline, barbiturates, and bacofen, very weak de-

Table 1 Primers for miRNA expression vectors

\begin{tabular}{|c|c|c|}
\hline & Forward & Reverse \\
\hline miR-15a & CCGCTCGAGTATTCTITGTGTTTCCTAACCTAT & GCGGAATTCTCAATAATACTGAAAAGACTATC \\
\hline miR-15b & CACCTCGAGCGGCCTGCAGAGATAATACTTC & GAGAATTCGTTGCTGTATCCCTGTCACACT \\
\hline miR-16-1 & GGGCTCGAGAAACATAGATTITTITACATGC & CCCGAATTCAATTCCTCTAATGCTGCATAAG \\
\hline miR-16-2 & CACCTCGAGCCTTAAAGTACTGTAGCAGCACAT & GAGAATTCGGTAAATCAAACACCAAGTGTACAG \\
\hline miR-103-1 & CCGCTCGAGTACTTCCCAATCCATTTAAAGTAT & GCGGAATTCAAGTAGCAGATAATTCAAATTG \\
\hline miR-103-2 & CGCCTCGAGTTCCAACAAATGTTTAATTACTTG & GGCGAATTCAAGTAGAGGAAGAGTGGAAGGT \\
\hline miR-107 & CACCTCGAGGATACAATTACAACCCATGTC & GAGAATTCCTGTCTTTCTAATATACCTCAGTG \\
\hline miR-137 & CACCTCGAGTTATGGATTTATGGTCCCGGTCAAG & GAGAATTCTCCAGTCCTGGTCACCAGAGGC^ \\
\hline miR-146a & CACCTCGAGATCCACCCACATCAGCCTTC & GGTTGAAGACTGAATTCGAGTAGCAGCAGCAGCAAGAGAG \\
\hline miR-146b & CACCTCGAGTCAGCTCCAAGCTCAGACCCTC & $\begin{array}{l}\text { GGTTGGTCTCGAATTCAGCACTGAGGAAGGACCAGCAT } \\
\text {. }\end{array}$ \\
\hline miR-181a-2 & CACCTCGAGTTCTCAGACATTCATTTGAGTC & CACGAATTCTCATCATGGACTGCTCCTTAC \\
\hline miR-181b-1 & GTTCTCGAGTATGACTAAAGGTACTGTTGTTTC & 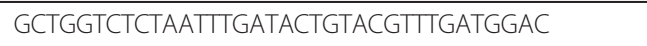 \\
\hline miR-181c & CACCTCGAGCTGCACTGCTACATCTCCATCC & GAGAATTCACACCAGCTCTCCTCTCCAAAG \\
\hline miR-181d & ATTCTCGAGCTCTCCTCCTCTCCCTCTTCATGCTC & ATAGAATTCAGATTGGGCCACTGCACTCCAGC \\
\hline miR-203 & ATTCTCGAGGCGGGGCTGGGCTTGGCGGCTG & TTTGAATTCGCGCGCCCCCACCCAGCGGTTC \\
\hline miR-216b & CCGCTCGAGTTTTCCTTCATTCTCTATGGAGAT & GGCGAATTCGATGCTAGTCTGGGAATCAAAC \\
\hline miR-221 & CACCTCGAGCGACCTTCCTTCCATCCAGCTT & GAGAATTCTTTGACAGTTGAGGCAGGGAGAAG \\
\hline miR-424 & CACCTCGAGCAGCTCCTGGAAATCAAATGGTG & GAGAATTCACTTACCCTGGCAGCGGAAACAATAC \\
\hline miR-497 & CACCTCGAGATGGTCCGTCGCCTTCCAGTTG & GAGAATTCTGGGTGTGGGCAACAAAGACTC \\
\hline
\end{tabular}


Table 2 Primers used for constructing 3'-UTR reporter vectors

\begin{tabular}{lll}
\hline Names & 3'-UTR or binding Sites & Sequences \\
\hline GABRA1-F-Spe I & 9-1962 & ggtactaGTCGTATTCTGTTGTTCAGTC \\
\hline GABRA1-R-PspOMI & gttgggccCTCTATACATGAAATGTCCTTGG \\
\hline GABRG2-F & GABRG2-R & GGCTAGTATGGACTTTACAATAAAAATGCTGCATTCTA \\
\hline
\end{tabular}

F: forward primers; R: reverse primers; microRNA binding sites are underlined

sensitization, a smaller single-channel conductance, and a longer open time [14-16]. Eight different subunits of $\mathrm{GABA}_{\mathrm{A}}$ and $\mathrm{GABA}_{\mathrm{C}}$ receptors $(\alpha 1-6, \beta 1-3, \gamma 1-3, \delta, \theta, \varepsilon$, $\pi$, and $\rho 1-3)$ have been identified. The assembly of a heteropentamer, with at least one $\alpha-$, one $\beta$-, and one $\gamma$ subunit, forms functional $\mathrm{GABA}_{\mathrm{A}}$ receptor channels. $\delta$-, $\theta-, \varepsilon-$, and $\pi$-subunits can substitute for the $\gamma$-subunit. However, $\mathrm{GABA}_{\mathrm{C}}$ receptors are exclusively composed of $\rho$ subunits in the form of homo- or hetero-pentamers.

To identify the microRNA that may potentially regulate $\mathrm{GABA}_{\mathrm{A}}$ and $\mathrm{GABA}_{\mathrm{C}}$ receptors, we used the online computer software, TargetScan (v 5.2) to predict the binding sites of microRNAs on the 3'UTR of rat GABA receptors. We chose rat GABA receptors because we use rats as most of our animal or cell models. Since our microRNA expression vectors use human sequences, we only queried conserved microRNA target sites among mammals based on conserved 8 mer and 7 mer sites that match the seed sequence of a microRNA. The results are listed in Table 3. Among $\alpha$-subunits, we found that $\alpha 1$ had most of the microRNA binding sites. There were 6 binding sites for 6 microRNAs on $\alpha 13$ 'UTR. For other $\alpha$-subunits, we found miR-128, miR$27 \mathrm{ab}$, let-7/miR-98 for $\alpha 6$. We did not find any microRNAs for $\alpha 2, \alpha 4$, and $\alpha 5$. There was no information available for $\alpha 3$.

For $\beta$-subunits, we found two binding sites for miR-30a/ $30 a-5 p / 30 b / 30 b-5 p / 30 / 384-5 p$ and one binding site for miR-103/107. There were 15 binding sites for 15 microRNAs on $\beta 2$ and 5 binding sites for 7 microRNAs on $\beta 3$. For $\gamma$-subunits, we found two binding sites on $\gamma 2$ and no binding sites on $\gamma 1$ and $\gamma 3$, There was only one binding site for $\varepsilon$ and no binding sites on $\pi_{-}, \delta_{-}, \theta-, \rho 1-$ and $\rho 2-$ subunits. In general, the "common" subunits $(\alpha, \beta$, and $\gamma)$ had more miRNA target sites than the "rare" subunits $(\delta$, $\theta, \varepsilon, \pi$, and $\rho$ ). This is probably because these subunits had shorter 3'-UTRs, in particular for $\rho$-subunits.

We also used another software, miRanda to predict the microRNA that target to GABA receptors (Table 3). In general, miRanda predicted more microRNAs than TargetScan. There were some common microRNAs that were predicted by both software. For example, miR-137, miR-181, miR-203, and miR-216a for $\alpha 1$; miR-103, miR107, miR-30, and miR-384-5p for $\beta 1$; and miR-204, miR-211, miR-23, and miR-26 for $\beta 3$.
We further utilized a recently developed software, miRWalk [33], to predict the miRNAs targeting 3'-UTR and open reading frame (ORF) of GABA receptors. The results are presented in Table 4. Obviously, this method is less stringent compared to TargetScan and miRanda, since the miRWalk query yielded 79 miRNAs for GABA receptor $\alpha 1$ subunit in comparison with only 6 by TargetScan and 29 by miRanda.

We selected two subunits, $\alpha 1$ and $\gamma 2$ for experimental verification of the predictions. For $\alpha 1$-subunit, we constructed a 3'-UTR reporter vector, in which the 3'-UTR of $\alpha 1$-subunit was placed after a Renilla luciferase reporter gene (Table 2). For $\gamma 2$-subunit, we cloned the predicted binding site of miR-103/107 into the downstream of a Renilla luciferase reporter gene. We then co-transfected a microRNA expression vector with the reporter into HEK293T cells to see whether the microRNA depressed the reporter activity. The firefly luciferase pGL3 vector was used for normalization. As shown in Figure 1, among the predicted microRNAs tested, miR-181, miR-216, and miR-203 inhibited the reporter activity. Four miR-181 isoforms, a-2, b-1, c and d-1 generated the same mature miR-181 and all of them depressed the reporter activity. All other microRNAs tested had no effects. The results suggest that miR-181, miR-216, and miR-203 are the micoRNAs that regulates GABA receptor $\alpha 1$-subunit. It is noted that miR-15, miR-16, miR-146, miR-221, miR-424 and miR-497 were predicated to target the GABA receptor $\alpha 1$-subunit by an earlier version (v.4.2) of TargetScan. Some of the miRNAs such as miR-181 are expressed in astrocytes naturally expressing GABA receptors [34]. For $\gamma 2$-subunit, we did not find major effects of miR-103-1, miR103-2, and miR-107 on the reporter activity (Figure 2).

It should be noted that we did not measure miRNA levels in the miRNA-overexpressed cells. Thus, there are possibilities that some of miRNAs may not be overexpressed in the experimental set-up; particularly for these miRNAs that had no effect on 3'-UTR reporter activity. However, the transfection efficiency is $90-100 \%$ under our experimental conditions based on the GFP reporter expression encoded in the same miRNA expression vector. Additionally, the effect of a miRNA on the luciferase activity does not necessarily mean that it was a direct effect on the binding of a miRNA to the 
Table 3 Predicted microRNAs targeting rat GABA receptor subunits by TargetScan and miRanda

\begin{tabular}{|c|c|c|c|c|c|}
\hline $\begin{array}{l}\text { GABA } \\
\text { receptor } \\
\text { subunits }\end{array}$ & $\begin{array}{l}\text { Entrez } \\
\text { Gene } \\
\text { symbol }\end{array}$ & $\begin{array}{l}\text { Lengths of } 3^{\prime} \text {-UTR } \\
\text { in TargetScan } \\
\text { (v5.2) }\end{array}$ & $\begin{array}{l}\text { Conserved microRNAs targeting to } \\
\text { GABA receptors predicted by } \\
\text { TargetScan (v5.2) }\end{array}$ & $\begin{array}{l}\text { Lengths of } 3^{\prime}- \\
\text { UTR in } \\
\text { miRanda }\end{array}$ & $\begin{array}{c}\text { Conserved microRNAs targeting to } \\
\text { GABA receptors predicted by } \\
\text { miRanda }\end{array}$ \\
\hline
\end{tabular}

al $\quad$ GABRA1 2017

miR-208/208ab,

2018

miR-499/499-5p, miR-181,

miR-216/216a, miR-137,

miR-203
miR-129 (2), miR-130b, miR-136, miR-

137, miR-148b-3p,

miR-150, miR-152, miR-181a (2) bc (3) d, miR-182,

miR-186, miR-203 (2), miR-210, miR216a, miR-26ab,

miR-30acde, miR-30b-5p, miR-320,

miR-340-5p, miR-361,

miR-374, miR-375, miR-376c, miR-377, miR-384-5p ,

miR-410, miR-433, miR-488 (2), miR539, miR-874

\begin{tabular}{|c|c|c|c|c|c|}
\hline$\alpha 2$ & GABRA2 & 747 & 0 & NA & NA \\
\hline$\alpha 3$ & GABRA3 & 0 & 0 & NA & NA \\
\hline$\alpha 4$ & GABRA4 & 7478 & 0 & 88 & $\begin{array}{l}\text { miR-186, miR-200bc, miR-203, miR-429, } \\
\text { miR-495 }\end{array}$ \\
\hline \multirow[t]{3}{*}{$\alpha 5$} & GABRA5 & 586 & 0 & 880 & $\begin{array}{l}\text { miR-124, miR-132, miR-133ab, miR-195, } \\
\text { miR-212, miR-223, }\end{array}$ \\
\hline & & & & & $\begin{array}{c}\text { miR-30acde, miR-30b-5p, miR-322, } \\
\text { miR-346, miR-376c }\end{array}$ \\
\hline & & & & & $\begin{array}{l}\text { miR-378, miR-384-5p, miR-494 (2), } \\
\text { miR-495, miR-539 }\end{array}$ \\
\hline \multirow[t]{2}{*}{$\alpha 6$} & GABRA6 & 809 & miR-128, miR-27ab, & NA & N/A \\
\hline & & & let7/miR-98 & & \\
\hline \multirow[t]{3}{*}{$\beta 1$} & GABRB1 & 407 & miR-30a/30a-5p/30b/30b-5p/ & 428 & $\begin{array}{l}\text { miR-103, miR-107, miR-128, miR-143, } \\
\text { miR-148b-3p, }\end{array}$ \\
\hline & & & 30/384-5p (2), miR-103/107 & & $\begin{array}{l}\text { miR-152, miR-30a (2) c (2) d (2) e (2), } \\
\text { miR-30b-5p (2), }\end{array}$ \\
\hline & & & & & miR-384-5p (2), miR-411 \\
\hline \multirow[t]{5}{*}{$\beta 2$} & GABRB2 & 5618 & miR-203,miR-135, miR-218, & 499 & $\begin{array}{l}\text { miR-128, miR-199a-5p, miR-203, miR- } \\
\text { 33, miR-411, miR-485 }\end{array}$ \\
\hline & & & miR-21/590-5p, miR-10, & & \\
\hline & & & miR-101, miR-19, miR-144, & & \\
\hline & & & miR-9 (2), miR-455/455-5p, & & \\
\hline & & & miR-33/33ab & & \\
\hline \multirow[t]{3}{*}{$\beta 3$} & GABRB3 & 4060 & miR-26ab/1297, miR-204/211, & 508 & $\begin{array}{l}\text { miR-122, miR-186, miR-199a-5p, miR- } \\
\text { 204, miR-210, miR-211, }\end{array}$ \\
\hline & & & miR-23ab, miR-27ab, miR-218 & & $\begin{array}{c}\text { miR-23ab, miR-26ab, miR-320, miR- } \\
\text { 324-5p, miR-329, }\end{array}$ \\
\hline & & & & & miR-381, miR-539 \\
\hline$\gamma 1$ & GABRG1 & 3428 & 0 & 240 & $\begin{array}{l}\text { miR-203, miR-218, miR-379, miR-410, } \\
\text { miR-455, miR-488 }\end{array}$ \\
\hline$\gamma 2$ & GABRG2 & 2106 & miR-150, miR-103/107 & NA & N/A \\
\hline$\gamma 3$ & GABRG3 & 96 & 0 & 114 & $\begin{array}{l}\text { miR-15b, miR-16, miR-195, miR-26ab, } \\
\text { miR-322, miR-497 }\end{array}$ \\
\hline$\pi$ & GABRP & 1178 & 0 & NA & $\mathrm{N} / \mathrm{A}$ \\
\hline$\delta$ & GABRD & 433 & 0 & 393 & $\begin{array}{l}\text { miR-145, miR-19ab, miR-24, miR-328, } \\
\text { miR-365 }\end{array}$ \\
\hline$\varepsilon$ & GABRE & 1485 & miR-22 & NA & N/A \\
\hline$\theta$ & GABRQ & 80 & 0 & NA & N/A \\
\hline$\rho 1$ & GABRR1 & 464 & 0 & NA & N/A \\
\hline$\rho 2$ & GABRR2 & 113 & 0 & 191 & 0 \\
\hline$\rho 3$ & GABRR3 & N/A & N/A & 271 & miR-191 \\
\hline
\end{tabular}

The conserved microRNAs targeting GABA receptors are predicted by Targetscan $5.2 \mathrm{http} / / / \mathrm{www}$. targetscan.org/ and miRanda software (http://www.microrna.org). The number in parenthesis is the number of the binding sites and none means one binding site. N/A means no information is available in TargetScan or miRanda 
Table 4 Predicted microRNAs targeting 5'-UTR, ORF and 3'-UTR region using miRWalk software

\begin{tabular}{|c|c|c|c|c|}
\hline $\begin{array}{l}\text { GABA receptor } \\
\text { subunits }\end{array}$ & $\begin{array}{c}\text { Entrez Gene } \\
\text { symbol }\end{array}$ & $\begin{array}{l}\text { MicroRNAs } \\
\text { targeting } 5^{\prime} \text {-UTR }\end{array}$ & MicroRNAs targeting ORF & $\begin{array}{c}\text { Numbers of microRNA targeting } 3^{\prime} \text {-UTR } \\
\text { with } p \text {-value }<0.05\end{array}$ \\
\hline \multirow[t]{3}{*}{$\alpha 1$} & GABRA1 & $\begin{array}{l}\text { miR-326, miR-28* } \\
\text { miR-29b-1* }\end{array}$ & miR-341, miR-503, miR-150, miR-378 & 79 \\
\hline & & $\begin{array}{l}\text { miR-539, miR-542-5p, } \\
\text { miR-147, }\end{array}$ & & \\
\hline & & miR-423, miR-598-5p & & \\
\hline$\alpha 2$ & GABRA2 & N/A & N/A & N/A \\
\hline \multirow[t]{4}{*}{$\alpha 3$} & GABRA3 & $\begin{array}{l}\text { miR-27b, miR-27a, } \\
\text { miR-185, }\end{array}$ & $\begin{array}{l}\text { miR-350, miR-431, miR-542-3p, miR- } \\
\text { 322, miR-323*, }\end{array}$ & 0 \\
\hline & & $\begin{array}{c}\text { miR-343, miR-346, } \\
\text { miR-17-5p }\end{array}$ & $\begin{array}{l}\text { miR-140, miR-148b-3p, miR-29a*, miR- } \\
\text { 152, miR-497 }\end{array}$ & \\
\hline & & $\begin{array}{l}\text { miR-93, miR-128, miR- } \\
143,\end{array}$ & & \\
\hline & & $\begin{array}{c}\text { miR-291a-5p, miR- } \\
\text { 20b-5p }\end{array}$ & & \\
\hline$\alpha 4$ & GABRA4 & $\mathrm{N} / \mathrm{A}$ & N/A & N/A \\
\hline \multirow[t]{2}{*}{$\alpha 5$} & GABRA5 & $\begin{array}{l}\text { miR-345, miR-22, miR- } \\
451 \text {, }\end{array}$ & $\begin{array}{c}\text { miR-24-1*, miR-24-2*, let-7d, miR-346, } \\
\text { miR-153, }\end{array}$ & 37 \\
\hline & & miR-541, miR-369 & miR-296, miR-376c, miR-466c & \\
\hline \multirow[t]{2}{*}{$\alpha 6$} & GABRA6 & 0 & $\begin{array}{c}\text { miR-126*, miR-743b, miR-323*, miR- } \\
\text { 330*, miR-21*, }\end{array}$ & 0 \\
\hline & & & miR-153, miR-880 & \\
\hline \multirow[t]{3}{*}{$\beta 1$} & GABRB1 & miR-323, miR-219-2 & $\begin{array}{l}\text { miR-140, miR-351, miR-324-5p, miR- } \\
\text { 325-3p, miR-7a*, }\end{array}$ & 26 \\
\hline & & & $\begin{array}{c}\text { miR-10a-5p, miR-125a-5p, miR-125b-5p, } \\
\text { miR-376b-5p, }\end{array}$ & \\
\hline & & & miR-384-3p & \\
\hline$\beta 2$ & GABRB2 & 0 & miR-20a*, miR-150, miR-297, miR-541 & 0 \\
\hline$\beta 3$ & GABRB3 & miR-188 & $\begin{array}{c}\text { miR-300-5p, miR-350, miR-433, miR- } \\
\text { 881, miR-672, }\end{array}$ & 17 \\
\hline \multirow[t]{3}{*}{$\gamma 1$} & GABRG1 & $\begin{array}{l}\text { miR-497, miR-322, } \\
\text { miR-103-2, }\end{array}$ & $\begin{array}{c}\text { miR-182, miR-216a, miR-483, miR-327, } \\
\text { miR-338, }\end{array}$ & miR-126*, miR- \\
\hline & & miR-103-1, miR-107 & miR-205, miR-296, miR-320, miR-880 & 379, miR-742, \\
\hline & & & & miR-871 \\
\hline$\gamma 2$ & GABRG2 & 0 & miR-182, miR-483, miR-382, miR-505 & 0 \\
\hline \multirow[t]{3}{*}{$\gamma 3$} & GABRG3 & $\begin{array}{l}\text { miR-151*, miR-125a- } \\
3 p\end{array}$ & $\begin{array}{l}\text { miR-142-3p, miR-298, miR-15b, miR-16, } \\
\text { miR-28, }\end{array}$ & 14 \\
\hline & & & $\begin{array}{l}\text { miR-34a, miR-195, miR-214, miR-290, } \\
\text { miR-449a, }\end{array}$ & \\
\hline & & & miR-880, miR-708 & \\
\hline$\pi$ & GABRP & miR-28, miR-708 & miR-345-5p, miR-199a-3p, miR-873 & 0 \\
\hline$\delta$ & GABRD & miR-210 & $\begin{array}{l}\text { miR-322, miR-338, miR-193, miR-370, } \\
\text { miR-497, miR-873 }\end{array}$ & 29 \\
\hline \multirow[t]{3}{*}{$\varepsilon$} & GABRE & 0 & $\begin{array}{l}\text { miR-485, miR-484, miR-342-3p, miR- } \\
\text { 344-5p, miR-223, }\end{array}$ & 0 \\
\hline & & & $\begin{array}{c}\text { miR-671, miR-322, miR-24, miR-139-3p, } \\
\text { miR-199a-5p, }\end{array}$ & \\
\hline & & & $\begin{array}{c}\text { miR-298, miR-483, miR-497, miR-743b, } \\
\text { miR-672 }\end{array}$ & \\
\hline \multirow[t]{2}{*}{$\theta$} & GABRQ & 0 & $\begin{array}{l}\text { miR-350, miR-34c, miR-92a, miR-92a, } \\
\text { miR-300-5p, }\end{array}$ & 0 \\
\hline & & & miR-92b, miR-7a*, miR-32 & \\
\hline \multirow[t]{2}{*}{$\rho 1$} & GABRR1 & miR-29b-1*, miR-26c & $\begin{array}{l}\text { miR-338, let-7d, miR-204*, miR-421, } \\
\text { miR-672, }\end{array}$ & 92 \\
\hline & & & miR-674-3p & \\
\hline
\end{tabular}


Table 4 Predicted microRNAs targeting 5?'?-UTR, ORF and 3?'?-UTR region using miRWalk software (Continued)

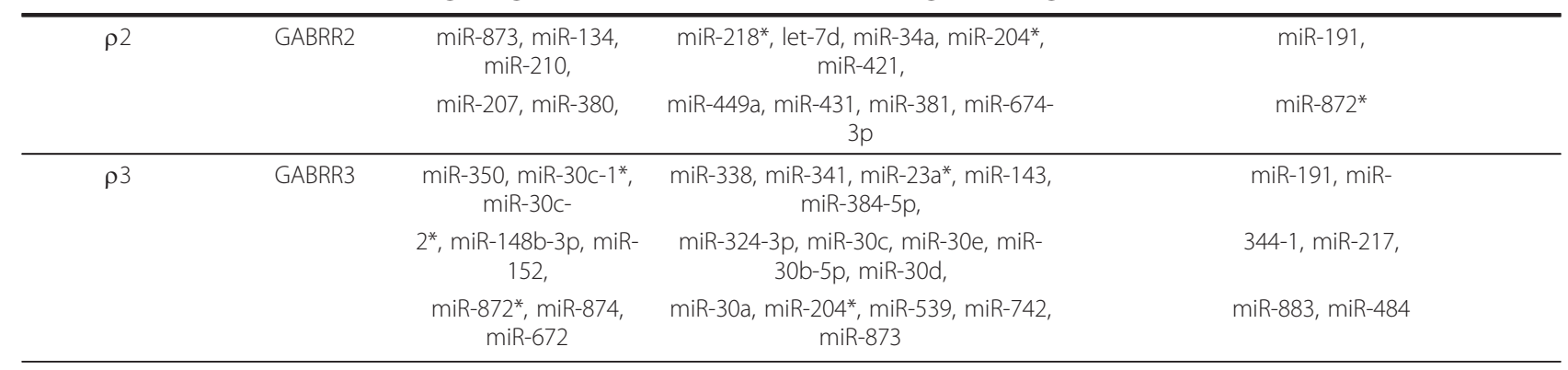

MicroRNAs which target 5'-UTR, open reading frame (ORF) and 3'-UTR of GABA receptors were predicted by miRWalk software http://www.ma.uni-heidelberg.de. $\mathrm{N} / \mathrm{A}$ means that no information is available in miRWalk

3'-UTR reporter construct. A miRNA could have indirect effects. The mutations of seed sequences in the miRNA binding sites are needed to exclude indirect effects. Further studies are also needed to see whether the overexpression of miR-181, miR-203, and miR-216 in a physiologically relevant cell type modifies GABA receptor expression, and whether these miRNAs are differentially regulated in diseased states.

It is also interesting to note that miR-15b and miR$146 \mathrm{a} / \mathrm{b}$ actually increased the 3'-UTR reporter activity. It has been reported that miRNA increases translation [35]. However, it is also possible that this is a result of indirect effects.
We have previously shown that the activation of GABA receptors promotes fetal lung development [13]. The inhibition of miRNAs that target GABA receptors may increase receptor density and thus sensitivity of GABA receptors, which may benefit the development of therapy in treating diseases related to developmental anomalies.

\section{Conclusions}

In summary, computational approaches predict many microRNA binding sites on the 3'-UTR of GABA receptors, but not on these of $\mathrm{GABA}_{\mathrm{C}}$ receptors. 3'UTR reporter assays only verified miR-181, miR-216,

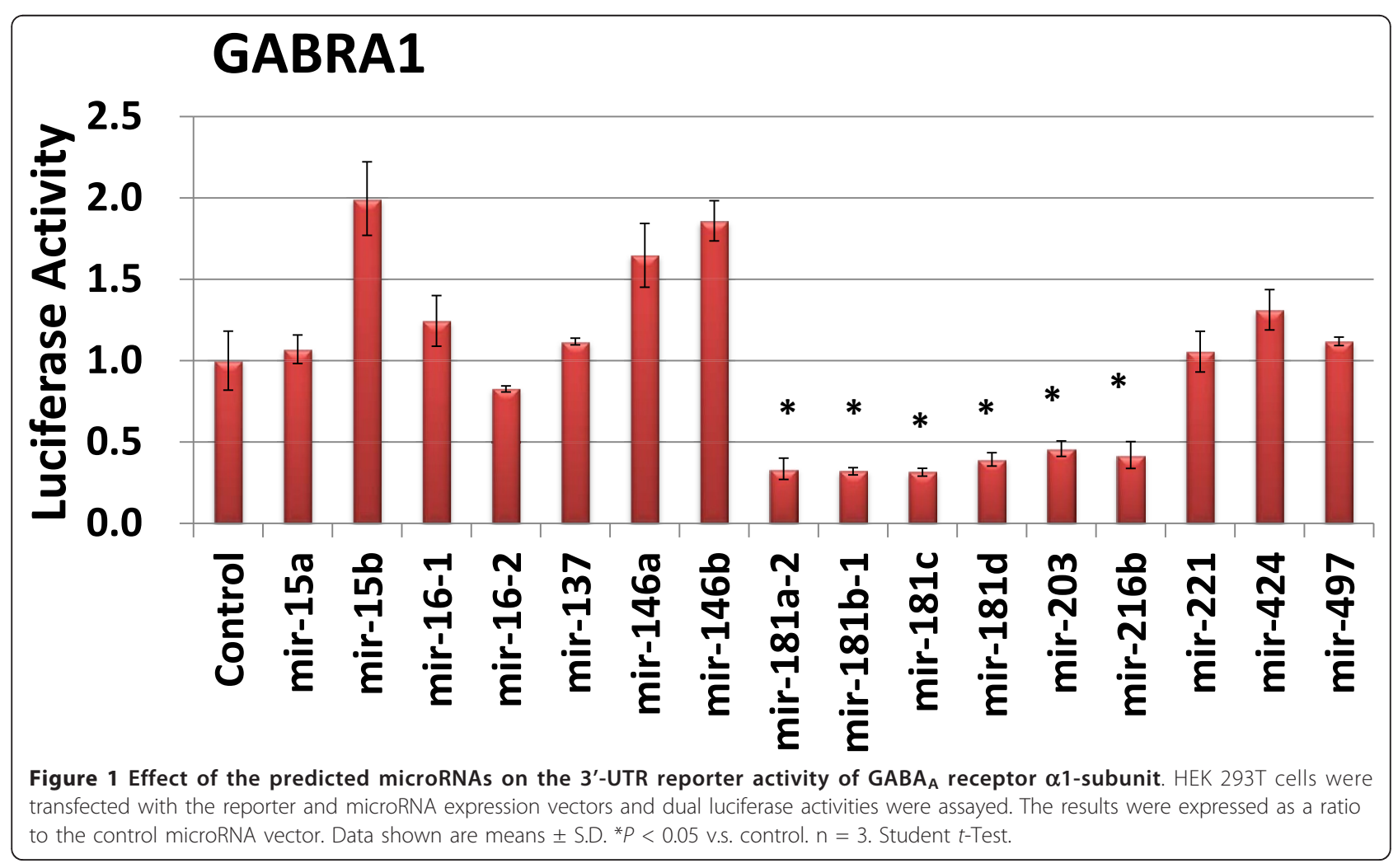




\section{GABRG2}
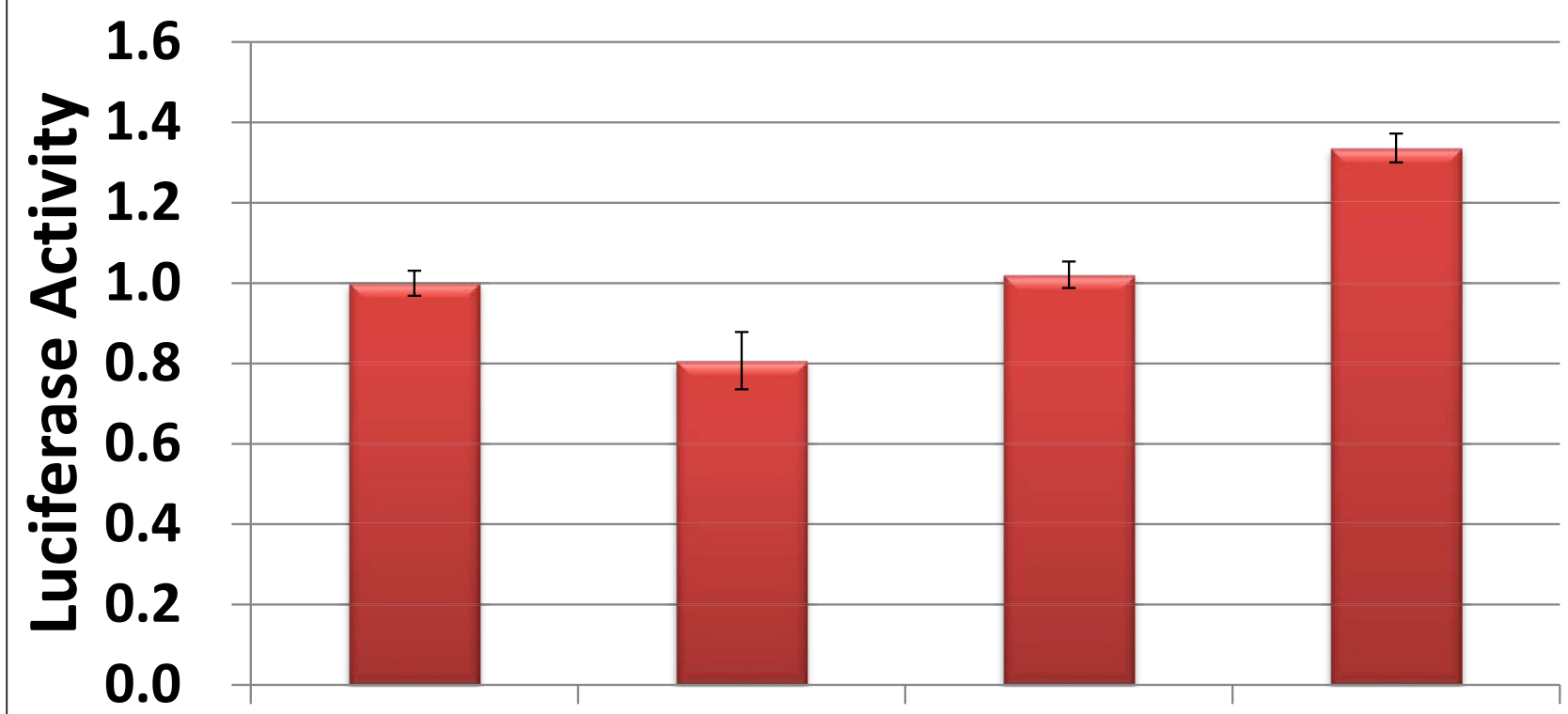

\section{Control}
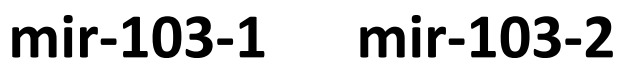

mir-107

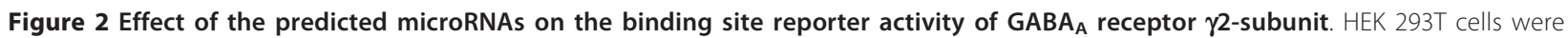
transfected with the reporter and microRNA expression vectors and dual luciferase activities were assayed. The results were expressed as a ratio to the control microRNA vector. Data shown are means \pm S.D. $\mathrm{n}=3$.

and miR-203 as the microRNAs that target GABA receptor $\alpha 1$-subunit among 10 microRNAs tested. These studies reinforce that micoRNA target prediction needs to be verified experimentally. The identification of microRNAs that target to GABA receptors provides a basis for further studies of post-transcriptional regulation of GABA receptors.

\section{Acknowledgements}

We thank Ms. Tazia Cook for editorial assistance. This work was supported by the National Institutes of Health, HL-087884 and HL-095383 and OCAST, AR101-037.

\section{Author details}

${ }^{1}$ The Lundberg-Kienlen Lung Biology and Toxicology Laboratory, Department of Physiological Sciences, Oklahoma State University, Stillwater, Oklahoma 74078, USA. ²Department of Physiology, Lu Zhou Medical College, Lu Zhou, Sichuan Province 64600, People's Republic of China. ${ }^{3}$ Department of Physiological Sciences, Oklahoma State University, 264 McElroy Hall, Stillwater, Oklahoma 74078, USA.

\section{Authors' contributions}

CZ, TW and HM carried out experiments. CZ, CH and XX analyzed data and performed target predictions. $L L$ conceived of the study, and participated in its design and coordination. $L L$ and $C Z$ drafted the manuscript. All authors read and approved the final manuscript.

\section{Competing interests}

The authors declare that they have no competing interests.

Received: 13 July 2011 Accepted: 9 February 2012 Published: 9 February 2012

\section{References}

1. Ben Ari Y: Excitatory actions of GABA during development: the nature of the nurture. Nat Rev Neurosci 2002, 3:728-739.

2. Owens DF, Kriegstein AR: Is there more to GABA than synaptic inhibition? Nat Rev Neurosci 2002, 3:715-727.

3. Akinci MK, Schofield PR: Widespread expression of GABA(A) receptor subunits in peripheral tissues. Neurosci Res 1999, 35:145-153.

4. Glassmeier $G$, Hopfner M, Buhr H, Lemmer $K$, Riecken EO, Stein $H_{\text {, }}$ Quabbe HJ, Rancso C, Wiedenmann B, Scherubl H: Expression of functional GABAA receptors in isolated human insulinoma cells. Ann N Y Acad Sci 1998, 859:241-248.

5. Park HS, Park HJ: Effects of gamma-aminobutyric acid on secretagogueinduced exocrine secretion of isolated, perfused rat pancreas. Am J Physiol Gastrointest Liver Physiol 2000, 279:G677-G682.

6. Jin N, Kolliputi N, Gou D, Weng T, Liu L: A novel function of ionotropic gamma-aminobutyric acid receptors involving alveolar fluid homeostasis. J Biol Chem 2006, 281:36012-36020.

7. Limmroth V, Lee WS, Moskowitz MA: GABAA-receptor-mediated effects of progesterone, its ring-A-reduced metabolites and synthetic neuroactive steroids on neurogenic oedema in the rat meninges. Br J Pharmacol 1996, 117:99-104.

8. Mong JA, Nunez JL, McCarthy MM: GABA mediates steroid-induced astrocyte differentiation in the neonatal rat hypothalamus. J Neuroendocrinol 2002, 14:45-55.

9. Mayerhofer A, Hohne-Zell B, Gamel-Didelon K, Jung H, Redecker P, Grube D, Urbanski HF, Gasnier B, Fritschy JM, Gratzl M: Gamma-aminobutyric acid (GABA): a para- and/or autocrine hormone in the pituitary. FASEB J 2001, 15:1089-1091.

10. Chen Z, Jin N, Narasaraju T, Chen J, McFarland LR, Scott M, Liu L: Identification of two novel markers for alveolar epithelial type I and II cells. Biochem Biophys Res Commun 2004, 319:774-780.

11. Jin N, Narasaraju T, Kolliputi N, Chen J, Liu L: Differential expression of $\mathrm{GABA}(\mathrm{A})$ receptor pi subunit in cultured rat alveolar epithelial cells. Cell Tissue Res 2005, 321:173-183. 
12. Jin N, Guo Y, Sun P, Bell A, Chintagari NR, Bhaskaran M, Rains K, Baviskar P, Chen Z, Weng T, Liu L: Ionotropic GABA receptor expression in the lung during development. Gene Expr Patterns 2008, 8:397-403.

13. Chintagari NR, Jin N, Gao L, Wang Y, Xi D, Liu L: Role of GABA receptors in fetal lung development in rats. PLoS One 2010, 5:e14171.

14. Bormann J: The 'ABC' of GABA receptors. Trends Pharmacol Sci 2000, 21:16-19.

15. Enz R, Cutting GR: Molecular composition of GABAC receptors. Vision Res 1998, 38:1431-1441.

16. Zhang D, Pan ZH, Awobuluyi M, Lipton SA: Structure and function of $\mathrm{GABA}(\mathrm{C})$ receptors: a comparison of native versus recombinant receptors. Trends Pharmacol Sci 2001, 22:121-132.

17. Moss SJ, Smart TG: Modulation of amino acid-gated ion channels by protein phosphorylation. Int Rev Neurobiol 1996, 39:1-52.

18. Bushati N, Cohen SM: microRNA functions. Annu Rev Cell Dev Biol 2007, 23:175-205.

19. Croce CM: Causes and consequences of microRNA dysregulation in cancer. Nat Rev Genet 2009, 10:704-714.

20. Lu Y, Thomson JM, Wong HY, Hammond SM, Hogan BL: Transgenic overexpression of the microRNA miR-17-92 cluster promotes proliferation and inhibits differentiation of lung epithelial progenitor cells. Dev Biol 2007, 310:442-453

21. Carraro G, El-Hashash A, Guidolin D, Tiozzo C, Turcatel G, Young BM, De Langhe SP, Bellusci S, Shi W, Parnigotto PP, Warburton D: miR-17 family of microRNAs controls FGF10-mediated embryonic lung epithelial branching morphogenesis through MAPK14 and STAT3 regulation of ECadherin distribution. Dev Biol 2009, 333:238-250.

22. Bhaskaran M, Wang Y, Zhang H, Weng T, Baviskar P, Guo Y, Gou D, Liu L: MicroRNA-127 modulates fetal lung development. Physiol Genomics 2009, 37:268-278.

23. Kumar MS, Erkeland SJ, Pester RE, Chen CY, Ebert MS, Sharp PA, Jacks T: Suppression of non-small cell lung tumor development by the let-7 microRNA family. Proc Natl Acad Sci USA 2008, 105:3903-3908.

24. Izzotti A, Calin GA, Arrigo P, Steele VE, Croce CM, De FS: Downregulation of microRNA expression in the lungs of rats exposed to cigarette smoke. FASEB J 2009, 23:806-812.

25. Liu G, Friggeri A, Yang Y, Park YJ, Tsuruta Y, Abraham E: miR-147, a microRNA that is induced upon Toll-like receptor stimulation, regulates murine macrophage inflammatory responses. Proc Natl Acad Sci USA 2009, 106:15819-15824

26. Sato T, Liu X, Nelson A, Nakanishi M, Kanaji N, Wang X, Kim M, Li Y, Sun J, Michalski J, Patil A, Basma H, Holz O, Magnussen H, Rennard SI: Reduced miR-146a increases prostaglandin Ein chronic obstructive pulmonary disease fibroblasts. Am J Respir Crit Care Med 2010, 182:1020-1029.

27. Polikepahad S, Knight JM, Naghavi AO, Oplt T, Creighton CJ, Shaw C, Benham AL, Kim J, Soibam B, Harris RA, Coarfa C, Zariff A, Milosavljevic A, Batts LM, Kheradmand F, Gunaratne PH, Corry DB: Proinflammatory role for let-7 microRNAS in experimental asthma. J Biol Chem 2010, 285:30139-30149.

28. Pandit KV, Corcoran D, Yousef H, Yarlagadda M, Tzouvelekis A, Gibson KF, Konishi K, Yousem SA, Singh M, Handley D, Richards T, Selman M, Watkins SC, Pardo A, Ben-Yehudah A, Bouros D, Eickelberg O, Ray P, Benos PV, Kaminski N: Inhibition and role of let-7d in idiopathic pulmonary fibrosis. Am J Respir Crit Care Med 2010, 182:220-229.

29. Cushing L, Kuang PP, Qian J, Shao F, Wu J, Little F, Thannickal VJ, Cardoso WV, Lu J: MIR-29 is a major regulator of genes associated with pulmonary fibrosis. Am J Respir Cell Mol Biol 2010, 45:287-294.

30. Liu G, Friggeri A, Yang Y, Milosevic J, Ding Q, Thannickal VJ, Kaminski N, Abraham E: miR-21 mediates fibrogenic activation of pulmonary fibroblasts and lung fibrosis. J Exp Med 2010, 207:1589-1597.

31. Zhang B, Pan X, Anderson TA: MicroRNA: a new player in stem cells. J Cell Physiol 2006, 209:266-269.

32. Betel D, Wilson M, Gabow A, Marks DS, Sander C: The microRNA.org resource: targets and expression. Nucleic Acids Res 2008, 36:D149-D153.

33. Dweep H, Sticht C, Pandey P, Gretz N: miRWalk-Database: prediction of possible miRNA binding sites by "walking" the genes of three genomes. J Biomed Inform 2011, 44:839-847.

34. Ouyang YB, Lu Y, Yue S, Giffard RG: miR-181 targets multiple Bcl-2 family members and influences apoptosis and mitochondrial function in astrocytes. Mitochondrion 2011 [http://dx.doi.org/10.1016/j. mito.2011.09.001].
35. Vasudevan S, Tong $Y$, Steitz JA: Switching from repression to activation: microRNAs can up-regulate translation. Science 2007, 318:1931-1934.

doi:10.1186/1756-0500-5-91

Cite this article as: Zhao et al:: Computational prediction of MicroRNAs targeting GABA receptors and experimental verification of miR-181, miR-216 and miR-203 targets in GABA-A receptor. BMC Research Notes 2012 5:91.

\section{Submit your next manuscript to BioMed Central and take full advantage of:}

- Convenient online submission

- Thorough peer review

- No space constraints or color figure charges

- Immediate publication on acceptance

- Inclusion in PubMed, CAS, Scopus and Google Scholar

- Research which is freely available for redistribution

Submit your manuscript at www.biomedcentral.com/submit
Biomed Central 